\title{
Awareness and Perception of Arbaminch Town Residents about Climate Change: A Cross Sectional Study
}

\author{
Habtamu Abebe* \\ Ethiopian Environment and Forest Research Institution, Dire Dawa Environment and Forest Research Center Dire Dawa, Ethiopia
}

Submission: October 23, 2019; Published: November 12, 2019

*Corresponding author: Habtamu Abebe, Ethiopian Environment and Forest Research Institution, Dire Dawa Environment and Forest Research Center Dire Dawa, Ethiopia

\begin{abstract}
Climate change has appeared to be one of the most devastating environmental threats in the current century. Assessing the awareness of the general population is an important measure to develop mitigation activities. The study aimed to investigate the awareness of communities for climate change and to analyze role of urban agriculture for climate resilience. The primary data was collected via survey research strategy through structured questionnaire. A cross-sectional survey was conducted in Arbaminch town. A pre-tested questionnaire was used in data collection to evaluate group differences for dichotomous variables. Logistic regression was also used to determine the strength of the association between factors. From the study, $87.2 \%$ respondents said they know about climate change and the rest $12.8 \%$ of respondents said they don't know about Climate change. Out of the total respondents $87.2 \%, 70.7 \%, 63.4 \%$, and $28 \%$ of them get information about climate change from media, family and friend, public meeting and lecture/ seminar respectively. Other sources of information accounted about $13.4 \%$ of the respondents' source of information. There was significant association between respondent's age, education level and occupation with awareness about climate change at the $5 \%$ significant level. Similarly, respondent's age, education level and occupation were also statistically significant with the perception of respondents regarding the importance of urban agriculture for climate change intervention. Therefore, policies and intervention programs aimed at promoting household level climate change awareness needs to be provided through different alternatives. Moreover, promoting urban agriculture will be important as climate resilience option.
\end{abstract}

Keywords: Climate change; Awareness; Perception; Urban agriculture

\section{Information}

The global average temperature has increased by $0.78^{\circ} \mathrm{C}$ between 1850 and 2012. Intergovernmental Panel on Climate Change [1] noted the projected increase will range from $1.5^{\circ} \mathrm{C}$ to $2^{\circ} \mathrm{C}$ towards the end of the 21 st century. According to the recent fourth assessment report of the Intergovernmental Panel on Climate Change [1], warming of the climate system is unequivocal, as is now evident from observations of increases in global average air and ocean temperatures. Widespread melting of snow and ice and rising global average sea level was also observed [2].

The impact of climate change is predicted to be severe in the coming years. It was also become clear that many of the causes of climate change are anthropogenic in nature through lifestyles, consumption and choices that pollute and exploit resources in an unsustainable manner [3].

The general population should be sensitized regarding global warming and climate change. Developing motivation for voluntary mitigation is mostly dependent on perceived susceptibility to threats and severity of climate change or climate variability im pacts. To address these issues effectively, it is essential to assess awareness regarding climate change in the general population [4]

Community awareness and knowledge is an important factor in combating climate. Despite the importance of climate change as a prerequisite for the adaptation strategy, little is known about societies' climate perceptions and their effects on adaptation decision due to lack of information facilities and awareness raising [5]. Communities' perception of climate change and their attitude towards climate change adaptation showed that higher experience of farming is positively correlated with higher degree of perception and knowledge about the climate change and associated problems [6]. Urban agriculture can play an important role in improving the urban environment and climate change and (to a lesser extent) mitigation as suggested by World Meteorological Organization [7].

Ethiopia is an agricultural country and its economy is mainly dependent on the rain fed agriculture. It has been affected by recurrent drought for a long time. The failure of seasonal rainfall 
adversely affects the country's socio-economy, in particular food production. The present study was conducted with the aim of assessing the awareness and perception of the urban general population residing in Arbaminch town regarding climate change and interventions. Cross sectional data from households located at three kebeles (the lowest administrative units) has been collected and analyzed.

\section{Methods and Material}

\section{Study area}

The study area is located approximately between $37028^{\prime}$ $54^{\prime \prime} \mathrm{E}$ to $37036^{\prime} 45^{\prime \prime} \mathrm{E}$ and $505^{\prime} 16^{\prime \prime} \mathrm{N}$ to $6005^{\prime} 14^{\prime \prime} \mathrm{N}$ in South Nations, Nationalities, and peoples' Regional State (SNNPRS). It is located about $500 \mathrm{~km}$ away from Addis Ababa, the capital city of Ethiopia. The study site is bordered with Lake Abaya in the East,
Lake Chamo in South-East and the ridge of the Great African Rift in the West. It is also bounded in between River Sile in South and River Harre in North. River Kulfo crosses the town at the northern side and flow South-East direction into Lake Chamo. The Great East African Rift Valley and the two lakes basins (Abaya and Chamo) are dominant physical features of the study area. The elevation varies from $1108 \mathrm{~m}$ at Lake Chamo up to 1800 masl.

The agro-climatic zone of the study area is characterized by dry Kola with its average annual temperature of $280 \mathrm{C}$ and $895 \mathrm{~mm}$ of average annual rainfall. The major economic activity in the town is trade. Tropical fruit plantations and cotton production, reliant on irrigation from the nearby lakes and rivers are also common in the region. Traditional fishing is also a major livelihood of the Arba Minch residents (Figure 1).

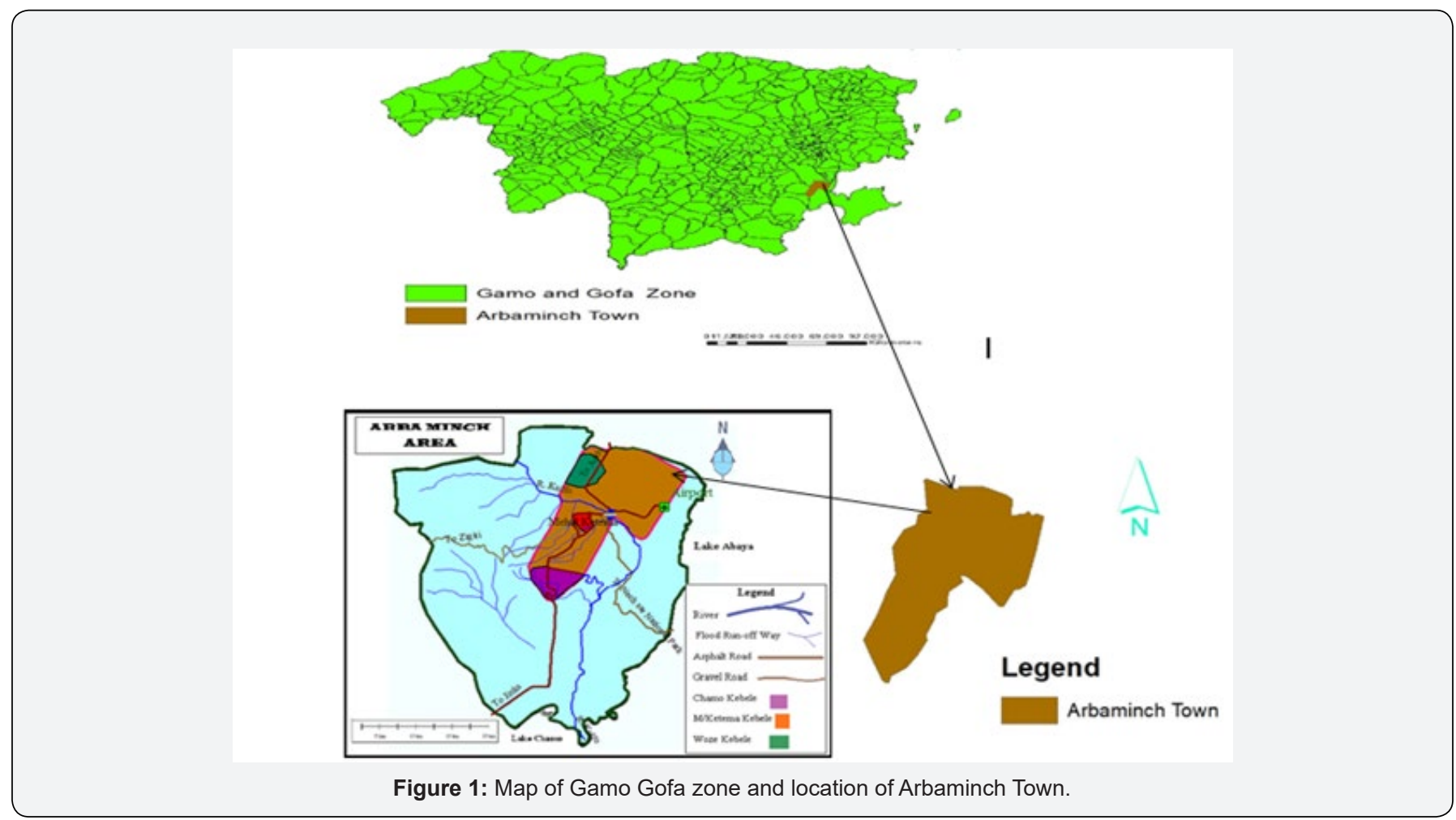

\section{Study design and period}

A quantitative cross-sectional study design has been used in this research. A quantitative research is generally associated with the positivist/postpositivist paradigm. It usually involves collecting and converting data into numerical form so that statistical calculations can be made, and conclusions drawn. In quantitative research a hypothesis which predicts relationships and associations between the things to be investigating (variables) should be conducted. Based on this approach we have developed a hypothesis regarding the association between demographic characteristics with the knowledge and awareness of residents. Factors determining the level of awareness and knowledge among residents were also investigated. The study was conducted from November to December 2016.

\section{Source and study population}

All households at Arbaminch were the source population of this study. The study population was all selected households included in those kebeles which were purposely selected as areas where urban agricultural practice was common.

\section{Sample size and sampling procedure}

The study followed multistage sampling procedures with individuals as the ultimate sampling unit to acquire primary data. From the total number of kebeles, three kebeles which practice urban agriculture were selected using purposive sampling. The sample size for the households'/respondent's survey was determined using single proportion formula (Kothari, 2004). The following formula was used to determine the size of the sample. 


$$
\begin{gathered}
n=\frac{z^{2} \cdot p \cdot q \cdot N}{e^{2}(N-1)+Z^{2} \cdot P \cdot q} \\
\frac{(1.82)^{2}(0.5)(0.5) 5409}{(0.07)^{2}(5409-1)+(1.82)^{2}(0.5)(0.5)}
\end{gathered}
$$

Where $\mathrm{n}=$ desired sample size when target population is less than 10,$000 ; \mathrm{N}=$ total number of households in three kebeles, $\mathrm{z}=$

Table 1: Distribution of sampled house hold by kebeles.

\begin{tabular}{|c|c|c|c|}
\hline Kebele & Total Number of HH in Each Kebele & Proportion & Sample Size from Each Kebele \\
\hline Woze & 2655 & $\frac{2655}{5409} \times 164$ & 31 \\
\hline Mehal ketema & 1214 & $\frac{1214}{5409} \times 164$ & 46 \\
\hline Chamo & 1540 & $\frac{1540}{5409} \times 164$ & 164 \\
\hline Total & 4479 & & 37 \\
\hline
\end{tabular}

\section{Data collection}

Primary data at the household level was collected through a household survey using structured questionnaire. Primary data was collected through questionnaires containing close ended questions. After preparing the questionnaires in English language, it was translated into the local language Amharic. A pre-test was collected in other kebeles before the actual data collection was conducted. The investigator checked the collected pre-test data to maintain its accuracy, completeness, clarity and consistency. Any error, related to clarity, ambiguity, incompleteness, or misunderstanding were solved before beginning actual data collection activities. To make the subjects respond freely, the data collection process was conducted confidentially, and the duration of data collection was as short as possible.

\section{Data processing and analysis}

The collected data were coded and entered using Statistical Package for Social Sciences (SPSS) software version 20.0. Data were cleaned accordingly for further analysis. The frequency distribution of dependent and independent variables was computed. Descriptive statistics including frequency and percentage were calculated and presented in tables, graphs and charts. The Chi-square test of independence was used to evaluate group differences for dichotomous variables .Logistic regression was also used to determine the strength of the association between factors, in this study, for example, if age group could be used to predict the awareness of the respondents regarding climate change $1=$ "Yes", 0 = "No").

\section{Results and Discussion}

\section{Results}

\section{Demographic characteristics of respondents}

Demographic data provides the readers with a picture of the
Value of standard variation, $\mathrm{e}=$ Acceptable error, $\mathrm{p}=$ the proportion of the target population estimated to have characteristics being measured ( $50 \%$ is taken or 0.5$), d=$ level of statistical significance, and $q=1$-p.Then $p=0.5, q=0.5$ considering $95 \%$ level of confidence, the related standard normal deviate is $\mathrm{z}=1.82$ and the desired accuracy is at 0.07 level (Table 1 ).

Then the sample size is; $=\frac{4479}{27.3273}=164$ demographic and socio-economic composition of the respondents. Accordingly, demographic data in this study comprises age, gender, educational status, occupation and monthly income level of the sample households in the town. The demographic and socio-economic characteristic of the sample households is described

\begin{tabular}{|c|c|c|c|}
\hline \multicolumn{2}{|c|}{ Variable } & Frequency & Percentage \\
\hline \multirow{2}{*}{ Gender } & Male & 105 & 64 \\
\hline & Female & 59 & 36 \\
\hline \multirow{5}{*}{ Educational Level } & Illiterate & 55 & 33.5 \\
\hline & $\begin{array}{l}\text { Elementary } \\
\text { School }\end{array}$ & 31 & 18.9 \\
\hline & High School & 44 & 26.8 \\
\hline & College diploma & 19 & 11.6 \\
\hline & Degree & 15 & 9.1 \\
\hline \multirow{4}{*}{ Occupation } & Government & 30 & 18.3 \\
\hline & Merchant & 52 & 31.7 \\
\hline & Farmer & 48 & 29.3 \\
\hline & Others & 34 & 20.7 \\
\hline \multirow{4}{*}{ Age } & $18-30$ & 46 & 28 \\
\hline & $31-40$ & 63 & 38.4 \\
\hline & $41-59$ & 42 & 25.6 \\
\hline & $\geq 60$ & 13 & 7.9 \\
\hline
\end{tabular}
in Table 2.

Table 2: Socio demographic characteristics of respondents.

Most of the respondents were males 105 (64\%) and the rest 59 (36\%) were females. Among the total respondents 59 (35\%) of the respondents had no education, while $31(18.9 \%)$ and 44 (26.8\%) attained primary and secondary education respectively. The mean age of respondents in the study was found to be 30.29 years with standard deviation of .917; the younger age of the respondent was 18 whereas the older age is 64 years. Whereas $11.6 \%$ and $9.1 \%$ of them obtained college diploma and degree. Re- 
garding the occupation category as illustrated in Table 2 that majority of respondents were Merchant (31\%) followed by farmers (29.3\%). Government employees consisted only 18.3\% The rest $20.7 \%$ of them were engaged in other activities.

\section{Respondent's awareness on climate change}

To have a reliable number on the frequency of climate change knowledge a researcher is required to manifest the society's knowledge on climate change. To asses knowledge about Climate change, the society's awareness was assessed using questions with Yes or No answer. $87.2 \%$ of respondents said they have knowledge on climate change and the rest $12.8 \%$ of respondents didn't know about climate change.

\section{Source of climate change information}

Table 3: Respondents source of information regarding climate change.

\begin{tabular}{|c|c|c|c|}
\hline $\begin{array}{c}\text { Source of Climate } \\
\text { Change Information }\end{array}$ & Category & Frequency & Percentage \\
\hline \multirow{2}{*}{ Lecture and Seminars } & Yes & 46 & 28 \\
\cline { 2 - 4 } & No & 118 & 72 \\
\hline \multirow{2}{*}{ Media } & Yes & 143 & 87.2 \\
\cline { 2 - 4 } & No & 21 & 12.8 \\
\hline \multirow{2}{*}{ Family and Friends } & Yes & 116 & 70.7 \\
\cline { 2 - 4 } & No & 48 & 29.3 \\
\hline \multirow{2}{*}{ Public Meeting } & Yes & 104 & 63.4 \\
\cline { 2 - 4 } & No & 60 & 36.6 \\
\hline \multirow{2}{*}{ Others } & Yes & 22 & 13.4 \\
\cline { 2 - 4 } & No & 142 & 86.6 \\
\hline
\end{tabular}

Respondent's accessed information from different sources as presented in Table 3. Mainstream Media was the major source of information as took the first source of climate change information as mentioned by $87.2 \%$ of respondents followed by family and friends which accounted 70.7\%. Public meeting 63.4\%, and Lecture and Seminar $28 \%$ come third and fourth. Other source of information like newspaper, posters, pamphlets, church/ mosque and books were also mentioned.

\section{Respondents view on weather and climate variability}

Table 4: Respondents perception regarding variability in climate parameters.

\begin{tabular}{|c|c|c|c|}
\hline Characteristics & Correct Answer & Frequency & Percentage \\
\hline Temperature & Increasing & 164 & 100 \\
\hline \multirow{2}{*}{ Rainfall } & Decreasing & 127 & 77.5 \\
\cline { 2 - 4 } & No change & 37 & 22.5 \\
\hline \multirow{2}{*}{$\begin{array}{c}\text { Dry Season Tem- } \\
\text { perature }\end{array}$} & Increasing & 149 & 90.9 \\
\cline { 2 - 4 } & No change & 15 & 9.1 \\
\hline \multirow{2}{*}{\begin{tabular}{c} 
Dry Season Rainfall \\
Wet Season Tem- \\
\cline { 2 - 4 } perature
\end{tabular}} & Decreasing & 123 & 75 \\
\cline { 2 - 4 } & No change & 41 & 25 \\
\cline { 2 - 4 } & Increasing & 131 & 79.9 \\
\hline \multirow{2}{*}{\begin{tabular}{c} 
Wet Season Rainfall \\
\cline { 2 - 4 }
\end{tabular}} & No change & 28 & 3 \\
\cline { 2 - 4 } & Decreasing & 112 & 68.3 \\
\hline
\end{tabular}

Table 4 below summarized the view of the respondents on the climate elements variability (temperature and rainfall variation). Most of the respondents responded that temperature of the town is increasing, and rainfall of the town is decreasing. Overall $100 \%$ of respondents agreed that temperature of the town is increasing and $77.5 \%$ of respondent's perceived decreasing trend in rainfall. While $22.5 \%$ of respondent's agreed that there is no change in the trend of rainfall at the town.

Table 5: Chi-square test of independence regarding climate change awareness and importance of urban agriculture for climate change intervention.

\begin{tabular}{|c|c|c|c|c|c|c|}
\hline \multirow[t]{2}{*}{ Category } & \multicolumn{2}{|c|}{ Do you know about Climate Change } & \multirow[t]{2}{*}{$\mathrm{X}^{2}$ (P-value) } & \multicolumn{2}{|c|}{$\begin{array}{l}\text { Urban Agriculture Important for Climate } \\
\text { Change Intervention }\end{array}$} & \multirow[t]{2}{*}{$\mathrm{X}^{2}$ (P-value) } \\
\hline & Yes & No & & Yes & No & \\
\hline \multicolumn{7}{|l|}{ Gender } \\
\hline Male & 92 & 13 & $0.047(0.504)$ & 79 & 26 & $0.11(0.44)$ \\
\hline Female & 51 & 8 & & 43 & 16 & \\
\hline \multicolumn{7}{|l|}{ Age } \\
\hline $18-30$ & 45 & 1 & $19.7(0.000)$ & 37 & 9 & $10.02(0.018)$ \\
\hline $31-40$ & 57 & 6 & & 49 & 19 & \\
\hline $41-59$ & 34 & 8 & & 31 & 11 & \\
\hline$\geq 60$ & 7 & 6 & & 5 & 8 & \\
\hline \multicolumn{7}{|l|}{ Education } \\
\hline Illiterate & 36 & 19 & $35.4(0.000)$ & 30 & 25 & $19.9(0.001)$ \\
\hline Primary & 31 & 0 & & 27 & 4 & \\
\hline Secondary & 43 & 1 & & 35 & 9 & \\
\hline Diploma & 18 & 1 & & 15 & 4 & \\
\hline $\begin{array}{l}\text { Degree and } \\
\text { above }\end{array}$ & & & & 15 & 0 & \\
\hline
\end{tabular}




\section{International Journal of Environmental Sciences \& Natural Resources}

\begin{tabular}{|c|c|c|c|c|c|c|}
\hline Occupation & & & & & & \\
\hline Govt Employed & 28 & 2 & $9.4(.0 .025)$ & 28 & 2 & $7.84(0.049)$ \\
\hline Farmer & 36 & 12 & & 36 & 12 & \\
\hline Merchant & 47 & 5 & & 35 & 17 & \\
\hline Other & 32 & 2 & & 23 & 11 & \\
\hline \multicolumn{7}{|l|}{ Income } \\
\hline$<600$ & 9 & 2 & $2.05(0.56)$ & 7 & 4 & $0.811(0.847)$ \\
\hline $600-1200$ & 11 & 3 & & 11 & 3 & \\
\hline $1201-2000$ & 41 & 7 & & 36 & 12 & \\
\hline$>2001$ & 82 & 9 & & 68 & 23 & \\
\hline
\end{tabular}

The respondents were also asked if there is a variation in climate elements during dry and wet season. Among the respondents $90.9 \%$ and $9.1 \%$ of respondent's perceived that dry season temperature is increasing and showed no change in the trend. Whereas, $75 \%$ and $25 \%$ of respondent perceived that there is decreasing trend and no change in dry season rainfall respectively. It also showed that $79.9 \%$ and $17.1 \%$ of respondents perceived an increasing and no change trend in wet season temperature. The rest $3 \%$ of respondent's perceived a decreasing trend of wet season temperature in the town. $68.3 \%$ and $31.7 \%$ of respondents believed that there is a decreasing trend and no change of trend in wet season rainfall (Table 5).

The result of a Chi-square test of independence suggested a significant association between respondents age X2(3) = 19.7, p $<0.001$, education level X2(4) $=35.4, \mathrm{p}<0.001$ and occupation $\mathrm{X} 2(3)=9.4, \mathrm{p}=0.025$ with awareness about climate change at the $5 \%$ significant level. The hypotheses that differences in awareness regarding climate change are related to differences in gender and income are not supported even at the $5 \%$ significant level.

Similarly, the result of a Chi-square test of independence which tested the association between respondents' demographic characteristics with their knowledge regarding the importance of urban agriculture for climate change intervention showed significant association. The respondents age X2(3) $=10.02, \mathrm{p}=0.018$, education level X2(4) = 19.9, $\mathrm{p}<0.018$ and occupation X2(3) = $7.84, p=0.049$ were statistically significant at $5 \%$ level of significance. The rest two variables (gender and income) were not statistically significant at the given level of significance.

Logistic regression was used to determine the odds that a "Yes" response to participants awareness about climate change and the importance of urban agriculture as intervention for climate change as a function of a set of demographic characteristics, including gender, age, education level, income level and occupation. Table 6 displays the findings concerning the awareness of respondents about climate change as a function of predictors. The model shows a positive relation between respondents' educational level and occupation with their awareness about climate change. The model indicates that respondents with diploma and above had more awareness compared to illiterate respondents and respondents who possessed primary and secondary level ed- ucation ( $\mathrm{p}=0.003)$. The results also showed respondent's awareness about climate change is more positive for residents with a higher level of education. It was also observed that, government employees had better awareness about climate change compared to farmers, merchants and others $(p=0.024)$.

Table 6: Summary of Logistic regression analysis for variables predicting awareness of respondents about climate change.

\begin{tabular}{|c|c|c|c|c|}
\hline Variables & $\begin{array}{c}\text { Estimated Coef- } \\
\text { ficient }\end{array}$ & $\begin{array}{c}\text { Standard } \\
\text { Error }\end{array}$ & Wald & Sig. \\
\hline Gender & -0.432 & 0.604 & 0.511 & 0.475 \\
\hline Age & -0.182 & 0.443 & 0.169 & 0.681 \\
\hline $\begin{array}{c}\text { Educational } \\
\text { Level }\end{array}$ & 1.484 & 0.507 & 8.575 & 0.003 \\
\hline Occupation & 0.913 & 0.404 & 5.116 & 0.024 \\
\hline Income & -0.101 & 0.285 & 0.127 & 0.722 \\
\hline Constant & -1.583 & 2.467 & 0.411 & 0.521 \\
\hline
\end{tabular}

-2 Log likelihood $=90.002$, Nagelkerke $R^{2}=0.355$.

Similarly, the logistic regression regarding respondents' response about the importance of urban agriculture as an intervention for climate change as a function of predictors is presented in Table 7. The model revealed that a positive relation between respondents' educational level with response of respondents. The model indicates that respondents with diploma and above had more awareness compared to illiterate respondents and respondents who possessed primary and secondary level education ( $\mathrm{p}$ $=0.019$ ).

Table 7: Summary of Logistic regression analysis for variables predicting perception of respondents about the importance of urban agriculture for climate change intervention.

\begin{tabular}{|c|c|c|c|c|}
\hline Variables & $\begin{array}{c}\text { Estimated Coef- } \\
\text { ficient }\end{array}$ & Standard Error & Wald & Sig. \\
\hline Gender & -0.085 & 0.415 & 0.042 & 0.838 \\
\hline Age & 0.03 & 0.315 & 0.009 & 0.925 \\
\hline $\begin{array}{c}\text { Educational } \\
\text { Level }\end{array}$ & 0.642 & 0.274 & 5.496 & 0.019 \\
\hline Occupation & -0.413 & 0.222 & 3.443 & 0.064 \\
\hline Income & -0.233 & 0.22 & 1.112 & 0.292 \\
\hline Constant & 1.596 & 1.737 & 0.845 & 0.358 \\
\hline
\end{tabular}

-2 Log likelihood $=169.3$, Nagelkerke R2 $=0.163$. 


\section{Discussion}

This study showed that respondents' awareness of climate change in terms of rainfall distribution, amounts, and increasing temperatures over the last several years. Respondents had wide perception in climate change, and majority of households perceived a notable change in rainfall and temperature. From the perspectives of the majority $100 \%$ of the respondents perceived that atmospheric temperature has been rising and, whereas $77.5 \%$ and $22.5 \%$, of the respondents perceived that rainfall has been on the decline and shows no change within the same period. The study communities have their own traditional ecological knowledge that can help them to build an understanding of climate change processes and phenomena across spatial and temporal scales for different years.

Access to the information on climate change characteristics is a very powerful tool that can be used to enhance the adoption and implementation of adaptation strategies by households [8]. Findings by [9] suggest that information and awareness on climate change could potentially serve as to successful implementation of adaptation practices. As the study indicates that majority of household respondents have different source of information about climate change. Media, Family and Friends, public meeting, trainings, church and mosques are identified source of climate change information to household respondents.

The 'Level of Perception for climate change is vary with the level communication and education of societies [10]. Education of the household head increases the probability of increasing awareness about climate change. Respondents' educational level is a positive relation with their awareness about climate change. Being educated significantly increases the level of awareness to climate change. Respondents with diploma and above had more awareness compared to illiterate respondents and respondents who possessed primary and secondary level education $\mathrm{p}=0.003$ (Table 6).

According to [7] urban agriculture is the way to build resilience to climate change. The present study result also indicates that urban agriculture as important for Climate change Intervention is positively and significantly related with education level of respondents. Increasing in the level of education has positive relation with the importance of urban Agriculture. Regarding to the importance of urban agriculture for climate change resilience sample respondents and key informants stated that urban agriculture helps to reduce heat waves by providing shades, increase the quality of the environment and aesthetic value by greening the environment, improve urban microclimate by purifying water and reducing air pollution, reduce flood impact, regulate disease by providing fresh food to the town, increase infiltration capacity to discharge water table, reduce soil erosion and land degradation which agrees with study undertaken by [11].

\section{Conclusion and Recommendation}

This study shows that there was good knowledge of Climate Change Among the community. The Study has revealed that the study societies has different source for climate change information and the study concluded that different information source for climate change were ground for the societies Climate change knowledge these Knowledge were acquired through formal education, media sources, friends and families at different level. The study has revealed urban agriculture practiced in the study area like crop production, vegetables and fruits or cash crops and mixed farming system as a minimum requirement for climate resilience. Therefore, policies and intervention programs aimed at promoting household level climate change awareness need to invest more on providing formal education, information services sources and better providing urban agriculture infrastructure as climate resilience.

\section{References}

1. International Panel on Climate Change (IPCC) (2013) Climate Change 2013: The Physical Science Basis, in Contribution of Working group I to the fifth assessment report of the International Panel on Climate Change. In: Stocker TF, Qin D, Plattner GK, et al. (Eds.), Cambridge Unversity Press, Cambridge, UK.

2. Bogner J, Pipatti R, Hashimoto S, Diaz C, Mareckova K, et al. (2008) Mitigation of global greenhouse gas emissions from waste: conclusions and strategies from the Intergovernmental Panel on Climate Change (IPCC) Fourth Assessment Report. Working Group III (Mitigation). Waste Management \& Research 26(1): 11-32.

3. Pandve HT, Chawla PS, Fernandez K, Singru SA, Khismatrao D, et al. (2011) Assessment of awareness regarding climate change in an urban community. Indian J Occup Environ Med 15(3): 109.

4. Shahid Z, Piracha A (2016) Awareness of climate change impacts and adaptation at local level in Punjab, Pakistan. Balanced Urban Development: Options and Strategies for Liveable Cities, pp. 409-428.

5. Tripathi A, Mishra AK (2017) Knowledge and passive adaptation to climate change: An example from Indian farmers. Climate Risk Management 16: 195-207.

6. Beharu Shikur (1993) Farmers perception of soil erosion problem and their attitude towards soil conservation in guraghe highlands of butajira awraja, south shoa Unpublished M.A. Thesis Department of Geography, Addis Ababa University.

7. World Metrological Organization (WMO) (2007) UN Agency calls for urban agriculture 2007. WMO press, Geneva, Switzerland.

8. International Panel on Climate Change (IPCC) Climate Change 2007: Impacts, Adaptation and Vulnerability. Contribution of Working Group II to the Fourth Assessment Report of the Intergovernmental Panel on Climate Change, Cambridge University Press.

9. Adger WN, Agrawala S, Mirza MMQ Conde C, O’Brien K, et al. (2007) Assessment of adaptation practices, options, constraints and capacity. Climate change.

10. International Panel on Climate Change (IPCC) (2007b) Climate change: Impacts adaptation and vulnerability. Contribution of working group II to the fourth assessment report of the intergovernmental panel on climate Change Cambridge University Press, New York.

11. Berhanu MA, Akola J (2014) Environmental Perspective of Urban Agriculture in Debre Markos Town, Ethiopia: Amhara Regional State. 
Your next submission with Juniper Publishers will reach you the below assets

- Quality Editorial service

- Swift Peer Review

- Reprints availability

- E-prints Service

- Manuscript Podcast for convenient understanding

- Global attainment for your research

- Manuscript accessibility in different formats

( Pdf, E-pub, Full Text, Audio)

- Unceasing customer service

Track the below URL for one-step submission https://juniperpublishers.com/online-submission.php 